\title{
MEMBANGUN SISTEM HUKUM PANCASILA YANG MERDEKA DARI KORUPSI DAN MENJUNJUNG HAM ${ }^{1}$
}

\author{
Teguh Prasetyo \\ Guru Besar Ilmu Hukum \\ Fakultas Hukum, Universitas Kristen Satya Wacana \\ Korespondensi: prof.teguh@gmail.com
}

\begin{abstract}
Abstrak
Sebagai negara yang sudah merdeka selama 68 tahun, Indonesia seharusnya sudah mempunyai sistem hukumnya sendiri yang sesuai dengan kepribadian bangsa Indonesia. Sistem hukum Indonesia tersebut harus dibangun berdasarkan Pancasila yang menampilkan karakteristik ke-Indonesia-an di tengah-tengah sistem hukum lain di dunia. Sistem hukum Pancasila merupakan suatu sistem hukum yang bermoral dan bermartabat. Bermoral berarti bahwa sistem hukum di Indonesia sistem hukum yang merdeka dari korupsi. Sedangkan sistem hukum yang bermartabat adalah sistem hukum yang menjunjung nilai-nilai kemanusiaan terutama di bidang HAM.
\end{abstract}

Kata-kata Kunci: Sistem Hukum; Pancasila; Bermoral; Bermartabat.

\begin{abstract}
Having been independent for 68 years, Indonesia should have had its own legal system that suits the character of the Indonesian nation. Indonesia's legal system have to be constructed based on Pancasila which reflects all the characteristics of Indonesia's particularity in the midst of other legal systems in the world. The legal system based on Pancasila is a legal system that emphasizes moral and human dignity. Legal morality means that the legal system in Indonesia is free from corruption. While the legal system with dignity is a legal system that upholds the values of humanity, especially in the field of human rights.
\end{abstract}

Key words: Legal System; Pancasila; Moral; Dignity.

Tulisan ini merupakan hasil revisi dari Orasi Ilmiah yang disampaikan dalam rangka memperingati Dies Natalis ke-57 Fakultas Hukum Universitas Kristen Satya Wacana, Salatiga, 6 Desember 2013. 


\section{PENDAHULUAN}

Korupsi merupakan masalah besar yang dihadapi oleh bangsa Indonesia. Bahkan tindak pidana korupsi di Indonesia sudah meluas di seluruh aspek kehidupan masyarakat. Bahkan kualitas tindak pidana korupsi yang dilakukan juga semakin tersistematis dengan lingkup yang memasuki seluruh aspek kehidupan masyarakat.

Korupsi lebih banyak terjadi pada sektor publik, yang sering dianggap sebagai masalah sosial yang serius, yang lebih ditentukan oleh faktor lingkungan kelembagaan. Pada mulanya korupsi yang terjadi di Indonesia disebabkan karena kondisi sosial ekonomi yang masih lemah sehingga motif orang melakukan korupsi misalnya oleh oknum-oknum pegawai adalah untuk mempertahankan hidup karena gajinya tidak cukup. Namun lama-kelamaan motif ini telah berubah dari sekedar mempertahankan hidup ke motif untuk memperoleh kemewahan.

Sistem hukum Indonesia secara umum tidak dipandang positif, badan yudisial dan kejaksaan juga dianggap sebagai lembaga publik yang paling korup. Hal ini juga diperkuat oleh ketidak berhasilan sistem hukum di Indonesia dalam memberantas dan mengurangi tindak pidana korupsi. Jika hal ini terus terjadi dalam waktu yang lama, maka dapat meniadakan rasa keadilan dan rasa kepercayaan masyarakat atas sistem hukum dan peraturan perundang-undangan Indonesia.
Korupsi merupakan suatu tindakan yang melanggar HAM, karena telah mengakibatkan hak orang lain dirampas, misalnya hak untuk mendapatkan kesejahteraan dan hidup yang layak. Padahal Indonesia berdasarkan UUD RI Tahun 1945 adalah Negara Hukum, yaitu negara yang berlandaskan hukum dan keadilan. Namun demikian perilaku korupsi tetap meluas dan dilakukan secara terorganisir dan sistematis yang telah memasuki seluruh aspek kehidupan masyarakat, sehingga hal ini telah menjadikan negara Indonesia sebagai salah satu negara terkorup di dunia.

Selama ini penanganan korupsi cenderung tambal sulam sehingga satu kasus korupsi belum selesai ditangani sudah ada kasus korupsi yang lain lagi. Oleh karena itu, dalam penanganan masalah korupsi, diperlukan penanganan secara holistik atau menyeluruh, yaitu melalui kontrol preventif. Kontrol preventif tersebut dilakukan dengan cara membangun sistem hukum yang kuat yaitu sistem hukum yang berlandaskan kepada nilainilai moral dan budaya bangsa Indonesia, yakni Pancasila. Dengan membentuk suatu sistem hukum yang berdasarkan pada Pancasila diharapkan dapat menimalisir terjadinya korupsi.

Hal ini mengacu pada apa yang terjadi di Korea Selatan, China dan Jepang yang menanamkan nilai-nilai moral dan budayanya masing-masing, sehingga dapat minimalisir terjadinya korupsi. Hal ini sebagai-mana yang dinyatakan oleh Shidarto Danusubroto, 
bahwa pendidikan moralitas dan budaya ditanamkan sejak dini seperti di negaranegara Korea Selatan, China dan Jepang. Meskipun di era globalisasi tetapi masih mempunyai karakter bangsa. Ketiga negara tersebut mendidik rakyatnya untuk disiplin, sopan, kerja keras dan bertanggung jawab, sehingga tingkat korupsinya kecil. ${ }^{2}$

\section{PEMBAHASAN}

\section{Pengertian Korupsi}

Korupsi merupakan suatu masalah yang sangat serius yang dihadapi oleh setiap negara. Sehingga hal tersebut juga mempunyai pengaruh terhadap pengertian korupsi itu sendiri sesuai dengan perkembangan zaman. Istilah korupsi berasal dari bahasa Latin yaitu coruptio atau corruptus yang berarti kebobrokan atau kerusakan.

Menurut Juniadi Suwartojo, korupsi adalah tingkah laku atau tindakan seseorang atau lebih yang melanggar norma-norma yang berlaku dengan menggunakan dan/atau menyalahgunakan kekuasaan atau kesempatan melalui proses pengadaan, penetapan pungutan penerimaan atau pemberian fasilitas atau jasa lainnya yang dilakukan pada kegiatan penerimaan dan/atau pengeluaran uang atau kekayaan, penyimpanan uang atau kekayaan serta dalam perizinan dan/ atau jasa lainnya dengan tujuan keuntungan pribadi atau golongannya sehingga langsung atau tidak langsung merugikan kepentingan dan/atau keuangan negara/masyarakat. ${ }^{3}$

Sementara menurut Baharuddin Lopa pengertian umum mengenai tindak pidana korupsi adalah suatu tindak pidana penyuapan dan perbuatan melawan hukum yang merugikan atau dapat merugikan keuangan negara atau perekonomian negara, merugikan kesejahteraan atau kepentingan rakyat. ${ }^{4}$

Korupsi jika dilihat dari bentuknya setidaknya dapat dikategorikan ada dua yaitu material corruption (korupsi material) dan political corruption (korupsipolitik).Material corruption adalah perbuatan memanipulasi keuangan Negara atau merugikan keuangan negara. Sedangkan yang termasuk korupsi politik menurut David M. Chalmers adalah korupsi pada pemilihan termasuk memperoleh suara dengan uang, janji-janji jabatan atau hadiah-hadiah khusus, paksaan intimidasi dan campur tangan terhadap kebebasan memilih. Korupsi dalam jabatan meliputi penjualan suara dalam legislatif, keputusan administratif atau keputusan pengadilan atau pengangkatan/penunjukkan oleh pemerintah. ${ }^{5}$

Dalam Undang-Undang Nomor 31 Tahun 1999 tentang Pemberantasan Tindak Pidana Korupsi disebutkan bahwa perbuatan korupsi adalah perbuatan yang mengandung lima

Kedaulatan Rakyat, 24 November 2013, hlm. 2.

<www.stialan.ac.id/artikel\%20yoqi.pdf> diakses 23 Agustus 2013.

Baharuddin Lopa, Masalah Korupsi dan Pemecahannya (Kipas Putih Aksara 1997) 4.

Ibid. 3. 
unsur, yaitu: Melawan hokum atau pertentangan dengan hukum; Memperkaya diri sendiri atau orang lain atau korporasi; Dapat merugikan keuangan Negara atau perekonomian Negara; Menguntungkan diri sendiri atau orang lain atau korporasi; dan Menyalahgunakan kewenangan, kesempatan, dan sarana yang ada padanya karena jabatan atau kedudukan.

Menurut Armen Yasir, korupsi dalam kehidupan sehari-hari akan menampilkan tiga bentuk, yaitu:

1. Korupsi epidemis; ruang lingkupnya berhubungan langsung dengan berbagai kegiatan pemerintahan yang menyangkut kepentingan masyarakat. Wujudnya dapat berupa jasa kesejahteraan masyarakat (pendidikan, perumahan, pertanian, listrik, dan lain sebagainya, perangkat undangundang (perpajakan, pengendalian harga dan sebagainya), sertajasa (SIM, KTP, Sertifikat Tanah, surat perizinan dan lain-lain);

2. Korupsi terencana, ruang lingkupnya berhubungan dengan tujuan-tujuan politis, bentuk ini sengaja direncanakan bagi keperluan operasional pemerintahan yang memang tidak dibiayai oleh anggaran (akan Nampak apabila berhubungan dengan suatu pemilihan, isu politik uang paling utama terjadi;
3. Korupsipembangunan, ruang lingkupnya berhubungan dengan fungsi pemerintah sebagai pengatur perekonomian yang memiliki peran penting dalam pemerintah sebagai pengatur perekonomian yang memiliki peran penting dalam berhubungan dengan para pengusaha, usahawan, importireksportis, produsen, penyalur dan sebagainya. ${ }^{6}$

\section{Konsep HAM}

Membicarakan HAM berarti membicarakan dimensi kehidupan manusia. HAM ada bukan karena diberikan oleh masyarakat atau kebaikan dari negara, melainkan berdasarkan martabatnya sebagai manusia. Setiap orang berhak memiliki hak asasi, di samping agar keabsahannya terjaga dalam eksistensi kemanusiaan, juga terdapat kewajiban yang sunguh-sungguh untuk dimengerti, dipahami, dan bertanggung jawab untuk memeliharanya. ${ }^{7}$

HAM merupakan prinsip yang mendasarkan pada anggapan bahwa manusia merupakan makhluk yang baik dan bermartabat. HAM merupakan hakhak fundamental yang realisasinya akan menjadikan manusia sebagai makhluk yang bermartabat. Hak-hak fundamental tersebut tidak saja sebagai kondisi yang memungkinkan manusia meng-ekspresikan dan mengaktualisasikan diri, melainkan juga kondisi yang

$6 \quad$ Armen Yasir, 'Penanggulangan Masalah Korupsi dari Perspektif Ketatanegaraan'(Seminar Dies Natalis ke-42, Universitas Lampung, Bandar Lampung, 6-7 September 2007).

$7 \quad$ Majda El-Muhtaj, Hak Asasi Manusia dalam Konstitusi Indonesia (Prenada Media Group 2007) 47. 
memungkinkan manusia dapat hidup terhormat. Keberadaan HAM tidak ditentukan oleh kemampuan merealisasikan hak tersebut.

Penegasan bahwa HAM bersifat universal dan tidak dapat dicabut, memberikan klaim atas kebebasan, perlindungan dan pelayanan yang esensial bagi semua orang. HAM bersifat universal ditujuan untuk mencegah agar warga Negara yang tertindas, anggota kelompok masyarakat minoritas atau golongan yang terkucilkan, tidak dibiarkan begitu saja tanpa memiliki hak yang dapat dituntut.

Sebagai negara yang berdasarkan hukum, Indonesia juga sangat menjunjung tinggi HAM. Hal ini dapat dilihat dari rumusan yang terdapat dalam pembukaan maupun dalam batang tubuh Undang-Undang Dasar Negara Republik Indonesia Tahun 1945 (UUD NRI 1945). Dalam Pembukaan UUD NRI 1945 dapat ditemukan dalam kalimat "kemanusiaan yang adil dan beradab”. Ini berarti bahwa adanya pengakuan bangsa dan negara Indonesia terhadap harkat dan martabat manusia dengan segala hak dan kewajiban asasinya”. Selain dalam Pembukaan UUD NRI 1945, ketentuan mengenai HAM juga telah diatur dalam batang tubuh UUD NRI 1945, yaitu di atur secara khusus dalam Bab XA mengenai HAM. Selain itu juga diatur dalam pasal-pasal yang lainnya, yaitu Pasal 27, Pasal 28, Pasal 29 ayat (2), Pasal 30 ayat (1), Pasal 31 ayat (1) dan ayat (2) UUD NRI 1945.
Dengan demikian maka negara Indonesia telah memberikan kedudukan yang tinggi dan mulia atas potensi dan martabat manusia. Karenanya ajaran HAM berdasarkan negara hukum Pancasila dijiwai dan dilandasi asas normatif theisme-religious:

1. Bahwa HAM adalah karunia dan anugerah Maha Pencipta (sila I dan II) sekaligus amanat untuk dinikmati dan disyukuri oleh umat manusia.

2. Bahwa menegakkan HAM senantiasa berdasarkan asas keseimbangan dengan kewajiban asasi manusia (KAM). Artinya, HAM akan tegak hanya berkat (umat) manusia menunaikan KAM sebagai amanat Maha Pencipta, sebagai integritas moral martabat manusia.

3. Kewajiban asasi manusia (KAM) berdasarkan filsafat Pancasila adalah:

a. Manusia wajib mengakui sumber (HAM: life, liberty, property) adalah Tuhan Yang Maha Pencipta (sila I) yang menganugerahkan dan mengamanatkan potensi kepribadian jasmani dan rohani sebagai martabat (luhur) kemanusiaan.

b. Manusia wajib mengakui dan menerima kedaulatan Maha Pecipta atas semesta, termasuk atas nasib dan takdir manusia.

c. Manusia wajib berterima kasih dan berkhidmat kepada Maha Pencipta, atas anugerah dan amanat yang 
dipercayakan kepada (kepribadian manusia). ${ }^{8}$

Oleh Albert Hasibuan, pemahaman HAM dalam negara hukum Pancasila, didasarkan pada:

1. HAM dipahami dalam terminologi hubungan atau relationship. Hak harus dilihat dalam hubungannya dengan masyarakat secara keseluruhan, dan pada saat yang sama masyarakat atau suatu komunitas berhubungan dengan hak-hak seorang individu;

2. Dalam pengembangan hak asasi manusia, berarti menerima adanya kewajiban atau tanggung jawab manusia, hak asasi manusia tidak dapat dibicarakan tanpa adanya implikasi langsung dari kewajiban masyarakat untuk menghormati HAM;

3. HAM harus dipahami sebagai satu kesatuan yang tidak dapat dipisahpisahkan. Pemahaman ini menunjukkan bahwa pada akhirnya hanya ada satu hak, yaitu hak untuk menjadi manusia, atau right to be human. ${ }^{9}$

Sistem Hukum Indonesia yang Merdeka dari Korupsi dan Menjunjung HAM

Sebagai negara yang sudah merdeka selama 68 tahun, Indonesia seharusnya sudah mempunyai sistem hukumnya tersendiri yang sesuai dengan kepribadian bangsa Indonesia. Adapun yang dimaksud dengan sistem hukum itu sendiri adalah keseluruhan aturan dan prosedur spesifik yang karena itu dapat dibedakan ciri-cirinya dari kaidahkaidah sosial yang lain pada umumnya, dan kemudian daripada itu yang secara relatif konsisten diterapkan oleh suatu struktur otoritas yang profesional guna mengontrol proses-proses sosial yang terjadi dalam masyarakat.

Perlunya sistem hukum tersendiri bagi Indonesia sudah sangat urgen atau mendesak, karena masyarakat sudah tidak percaya lagi pada sistem hukum yang ada pada saat ini, terutama dibidang penegakan hukum. Dalam perkembangannya, ternyata hukum telah mengalami kemajuan yang sangat pesat baik dari sudut teori maupun dalam praktek. Sehingga sistem hukum yang ada sekarang ini sudah ketinggalan zaman sehingga sudah tidak sesuai dengan keadaan yang terjadi pada saat ini. Terutama dalam hal pemberantasan korupsi dan penghormatan terhadap HAM.

Ketidaksesuaian tersebut disebabkan karena sistem hukum di Indonesia sebagian besar merupakan peninggalan kolonial Belanda yang menganut sistem civil law. Yang mengakibatkan kondisi hukum di Indonesia syarat dengan nuansa

8 Teguh Prasetyo dan Abdul Halim Barkatullah, Filsafat, Teori dan Ilmu Hukum: Pemikiran Menuju Masyarakat Yang Berkeadilan dan Bermartabat (PT. RajaGrafindo Persada 2012) 392-393.

$9 \quad$ Bagir Manan dkk., Perkembangan Pemikiran dan Pengaturan Hak Asasi Manusia di Indonesia (PT. Alumni 2006) 27.

10 Teguh Prasetyo dan Abdul Halim Barkatullah, Op.Cit. 83. 
positivistik yang mengakibatkan cara berhukum atau penegakan hukum di Indonesia terkungkung dalam bingkai formalistik. Karena pengaruh dari pemikiran legalitas formal tersebut maka sangat mempunyai dampak yang sangat besar terhadap pembentukan peraturan perundang-undangan baik ditingkat pusat maupun di tingkat daerah. Yang mana peraturan tersebut tidak ada peraturan pelaksananya dan tidak sinkron secara vertikal dan horisontal. Hal tersebut berdampak pula pada proses dan cara penegakan hukum di Indonesia selama ini. Oleh karena itu Indonesia perlu membangun suatu sistem hukum yang struktur dan nilai sosial masyarakat dan bangsa Indonesia.

Meskipun sulit untuk membangun sistem hukum tersendiri, namun tidak mustahil bagi Indonesia untuk mempunyai sistem hukumnya tersendiri yang digali berdasarkan kepada nilainilai yang tumbuh dalam masyarakat Indonesia serta berlandaskan kepada kepribadian bangsa Indonesia. Sebagaimana yang dinyatakan oleh Karl Von Savigny bahwa hukum itu tidak dibuat, melainkan tumbuh dan berkembang bersama masyarakat (das recht wird gemacht, est ist und wird mit dem volke). Oleh karena itu, Indonesia dalam membentuk sistem hukum harus didasarkan dan dilandasi oleh nilai-nilai kehidupan dan kebudayaan Indonesia yaitu Pancasila.Yang oleh para founding father, Pancasila telah ditetapkan sebagai falsafah dan dasar negara Indonesia. ${ }^{10}$

Diterimanya Pancasila sebagai falsafah dan dasar negara Indonesia telah menimbulkan konsekuensi logis untuk menjadikan Pancasila sebagai dasar bagi penyelenggaraan berbangsa dan bernegara, termasuk dalam hal berhukum. Dengan demikian tatanan sistem hukum di Indonesia harus mengacu pada cita hukum (rechtsidee) Pancasila. Dalam hal ini adalah dengan menjabarkan nilai-nilai Pancasila tersebut ke dalam hukum positif yaitu UUD 1945 dan peraturan perundangundangan dibawahnya.

Cita hukum (rechtsidee) Pancasila dalam pembentukan sistem hukum di Indonesia mempunyai fungsi sebagai tolak ukur yang bersifat regulatif dan konstruktif. Jika tanpa hal tersebut maka produk yang dihasilkan oleh hukum akan kehilangan maknanya. Sedangkan Hamid Attamimi mengatakan bahwa Pancasila sebagai cita hukum (rechtsidee) mempunyai dua fungsi yang fungsi konstitutif dan fungsi regulatif terhadap sistem norma hukum Indonesia secara konsisten dan terus menerus. ${ }^{11}$

Cita hukum Pancasila dalam pembangunan sistem hukum mempunyai tiga nilai, yaitu:

1. nilai dasar, yaitu asas-asas yang diterima sebagai dalil yang sedikit banyak mutlak. Nilai dasar Pancasila

Ibid. 68.

Winarno, Pendidikan Pancasila di Perguruan Tinggi (Yuma Pustaka 2012) 40-41.

Teguh Prasetyo dan Abdul Halim Barkatullah, Op.Cit. 85. 
tersebut adalah Ketuhanan, kemanusiaan, persatuan, nilai kerakyatan dan nilai keadilan.

2. nilai instrumental, yaitu pelaksanaan umum dari nilai-nilai dasar. terutama berbentuk norma hukum yang selanjutnya dikristalisasi dalam peraturan perundang-undangan.

3. nilai praktis, yaitu nilai yang sesungguhnya dilaksanakan dalam kenyataan. Nilai praksis sesungguhnya menjadi batu uji apakah nilai dasar dan nilai instrumental itu benar-benar hidup dalam maakat Indonesia. Misalnya kepatuhan masyarakat terhadap hukum atau penegakan hukum. ${ }^{12}$

Dengan demikian maka sistem hukum nasional yang hendak dibangun mencakup nilai-nilai Pancasila, yaitu:

1. Ketuhanan Yang Maha Esa. Artinya bahwa dalam pembentukan hukum di Indonesia harus dilandasi oleh nilai-nilai Ketuhanan atau keagamaan. Selain itu juga, dalam setiap pembentukan hukum harus ada jaminan bagi kebebasan beragama dan tidak boleh ada hukum yang mengistimewakan salah satu agama tertentu dan menganaktirikan agama yang lainnya;

2. Kemanusiaan yang adil dan beradab. Artinya bahwa dalam setiap pembentukan hukum harus adan jaminan dan penghormatan hak-hak asasi manusia;
3. Persatuan Indonesia. Ini berarti bahwa dalam pembentukan hukum harus memperhatikan persatuan atau integritas bangsa dan negara. Dalam pembentukan hukum tidak boleh mengakibatkan perpecahan (disintegrasi) dan memecah belah bangsa dan negara;

4. Kerakyatan yang dipimpin oleh hikmat kebijaksanaan dalam permusyawaratan perwakilan. Artinya bahwa dalam pembentukan hukum harus dilandasi oleh nilainilai demokratis yang melibatkan semua unsur yang ada di negara baik pemerintah, Legislatif maupun masyarakat;

5. Keadilan sosial bagi seluruh rakyat Indonesia. Artinya bahwa dalam pembentukan hukum nasional harus bertujuan untuk memberikan keadilan dan kesejahteraan bagi seluruh rakyat Indonesia. ${ }^{13}$

Nilai-nilai Pancasila tersebut kemudian dikonkretisasikan ke dalam norma-norma hukum. Pembangunan sistem hukum yang berlandaskan kepada Pancasila harus diarahkan untuk me-nampung dan mendukung kebutuhan-kebutuhan hukum sesuai dengan perkembangan dan kemajuan pembangunan yang terjadi di bidang lain, sehingga sistem hukum Pancasila mampu untuk menciptakan ketertiban dan kepastian hukum yang bertujuan untuk meningkatkan persatuan dan kesatuan bangsa dan negara. Serta mampu menangkal korupsi dan hukum yang menjunjung tinggi HAM. 